\author{
VIRA DODONOVA, \\ Borys Grinchenko Kyiv University (Kyiv, Ukraine) \\ e-mail:v.dodonova@kubg.edu.ua, ORCID 0000-0002-4282-5495 \\ ROMAN DODONOV, \\ Borys Grinchenko Kyiv University (Kyiv, Ukraine) \\ e-mail: rdodonov@kubg.edu.ua, ORCID 0000-0003-1598-499X
}

\title{
TRANSFORMATION OF SOCIAL VALUES DURING A PANDEMIC AND PROBLEMS OF GLOBAL SOLIDARITY
}

\begin{abstract}
The paper analyzes the current situation in the world during the coronavirus pandemic, in particular, the general trend to border closure, isolation, national selfishness, increase in total control, and "secucracy". The paper puts forward a question of reinterpretation of the significance of material values; actualization of post-material values: friendship, love, respect for the Other, self-actualization, family, and environmental values. Based on P. Sorokin's model of universal altruism, the value shift amidst the pandemic has been analyzed. It is proved that during the severe periods of human development the values of natural law, namely the right to life, the right to health, the right to freedom assume great importance.
\end{abstract}

Keywords: altruism; coronavirus; ecology; health; power.

\section{Introduction}

Today, humanity is experiencing a difficult, dramatic yet interesting period of its existence, the consequences of which are hardly predictable. We all find ourselves in an unusual situation about how to live now and how humanity will live in the future. This lack of definite future is likely to frighten both intellectuals and regular citizens. Life has got divided into two stages: before and after. And this division has become significant not only in the life of each individual, but also in the lives of states, and our planet in general. According to J. Shapiro, "the virus will pass and eventually we will come out of our homes. As after previous pandemics, we will be ashamed of how we responded, and we will wish to forget what we did. The $1918 \mathrm{flu}$ pandemic, which killed tens of millions of people, virtually disappeared from the history of the time. So, perhaps we will not speak of the coronavirus much. But both Europeans and Americans will remember that, when push came to shove, we were not in it together. We were the "other" (Shapiro, 2020).

The coronavirus pandemic has shown that the threats are not fictions but are quite real. Yuval Harari writes that "Humankind is now facing a global crisis. Perhaps the biggest crisis of our generation. The decisions people and governments take in the next few weeks will probably shape the world for years to come. ... When choosing between alternatives, we should ask ourselves not only how to overcome the immediate threat, but also what kind of world we will inhabit once the storm passes" (Harari, 2020).

As it turns out, pandemics demonstrate the worst sides of human nature, namely the natural selfishness and selfpreservation instinct inherent in any living being; we have a situation of Hobbes's War of All against All. Most emergencies show a quite high degree of people's unity; for example, during natural disasters, financial crises, even wars (when, however, the unity of one people opposes the unity of others), but this is still a consolidation against some common disaster. In contrast, pandemics are of a different nature; they separate and isolate people, they center around irrational features of humans, including fear and despair. However, the scope of a common disaster is no less than during wars and cataclysms. But human communities co-operate, make common cause or fall apart not only on the basis of irrational factors; on the contrary, there are rational levers of communication; such levers include the values of a human, society, and humanity. And, probably, the most important value, foundation, condition, and imperative on which humanity exists and should exist is solidarity.

The purpose of the paper is to analyze the universal altruism of P. Sorokin as a form of solidarity and transformation of values during and after a pandemic.

\section{Methodology}

The main methods that proved to be particularly useful for this paper were discourse analysis, which made it possible to see a multitude of understanding of the phenomena of pandemic, solidarity, values, filling of notions with specific political, epistemological, socio-cultural meaning; the phenomenological method enabled the analysis of the everyday experiences of people affected by the pandemic; the comparative method made it possible to compare the manifestations of a pandemic struggle in different countries, under different political regimes.

Results and discussion

The problem of solidarity is not new to the social sciences. The works of E. Durkheim, T. Parsons, P. Sorokin, A. Schütz, G. Blumer, N. Luhmann, J. Urry should be mentioned here, in which this problem is analyzed from various methodological positions. However, today the concept of universal altruism and universal solidarity of P. Sorokin is relevant. It is believed that philosophical texts 
are often utopian, and disconnected from reality. Nevertheless, they are often ahead of their time and are of a futuristic character. And let this futurism retain the essence of Kant's global categorical imperative, but it will surely "come through". One might ask if there is anything more naïve that the dream of universal altruism advocated by P. Sorokin. But it is this format of world relations which is being prompted by the situation of the pandemic.

\section{Model of universal altruism by P. Sorokin.}

P. Sorokin insists on the importance of forming a universal tendency to spread altruistic behavior, proposing measures for this. One of them is the intensification of the altruistic behavior of each individual. Another measure is to "channel negative human qualities in a positive direction. Firstly, one may use such universal human feelings as fear and hatred. They must be directed at combating human sorrows and "enemies" - deaths, diseases, crime, and poverty (Sorokin, 2002). Secondly, people's propensity for competition can be used. But it will not be a competition for territories, minerals, global domination, but for creation (Sorokin, 2002). Social and political groups must compete in finding the world's community which can save more people, provide better education and medical services, and create a masterpiece of art. The ultimate goal should be a united unanimous humanity.

In this regard, Sorokin writes: "As long as the members of a certain society or social universe cooperate with one another as neighbors, society has a peaceful and harmonious life. When cooperation with its sympathy and tolerance accompanying becomes depleted, social tension, animosity and antagonisms escalate" (Sorokin, 2002). P. Sorokin tries to solve the question of what contributes to the solidarity - repulsion or attraction. $\mathrm{He}$ concludes that only the value system provides for the possibility of attraction or repulsion. Therefore, creation of a system of values with common basic categories ensures the strengthening of the solidarity of any groups, even the antagonistic ones. Social solidarity can be formed "from various racial, ethnic, political, and religious groups, when, along with their specific values and norms, they have a common fund of basic values and agreed norms" (Sorokin, 1947). He continues that "unanimous humanity must overcome the boundaries that impede the creative interaction between people around the world. The states that form intragroup egoism and deny the possibility of intersection of moral and political realms are not able to achieve the goal of large-scale socio-cultural transformation since they operate in an outdated "coordinate system" (Sorokin, 1947).

P. Sorokin created not just a scientific model, but proposed a social project, the implementation of which depends on individual and collective efforts, and which becomes relevant in the challenging periods of humanity.

The pandemic outbreak evidenced that the first response of the countries was the border control and closure. This has thrown discredit on the progress of the states of the European Union in the area of cooperation. Each country has placed its own interests above those of the international community. As the former Minister of Foreign Affairs of Ukraine P. Klimkin noted, "the pandemic has revealed a terrible lack of solidarity, banal rivalry for medical equipment, poor cooperation even within the European Union due to a plain incoordination. It is frightening" (Klimkin, 2020).

There is a traceable trend of state selfishness, when no one thought about the common interests of global humanity. The pandemic contributed to the isolation of states and strengthened this trend. The coronavirus will either finally put an end to solidarity, or bring about a new quality of solidarity. Modern politicians should be aware of the fact that selfish relations will have bad consequences for future politics and international relations, since life in the European community is centered around not only on legislation but, above all, on trust and solidarity.

It is a good thing that common sense has prevailed, and the first selfish steps taken by countries to combat the pandemic have subsequently been replaced by friendly assistance. The discourse of national selfishness which is represented by $D$. Trump, who proclaimed the slogan "the United States Above All Else", unashamed of historical parallels with Nazi Germany, and this discourse is abandoned and replaced with a discourse of mutual assistance and support.

The pandemic has provoked a discussion of contemporary philosophers who express their own opinion on the need to make humanity unanimous. For instance, Yuval Harari emphasizes two contradictions, which determine the direction of the further development of mankind: "...we face two particularly important choices. The first is between totalitarian surveillance and citizen empowerment. The second is between nationalist isolation and global solidarity" (Harari, 2020).

Developing this thought, Eva Illouz writes: "This pandemic is like a movie trailer that offers a preview, a prototype, a premonition of what might happen if even more dangerous viruses appear, and a climate change would make the world unfit for human existence. If this occurs, it will no longer be possible to defend either private or public interests. Unlike those who foretell the revival of nationalism and return of borders, I am convinced that only a coordinated international response can help to deal with the new risks and disasters. The world is irrevocably interconnected, and future challenges can only be overcome through joint efforts" (Latour, Illusion, Jean-Luc, 2020).

In what way this global solidarity can be manifested in? Y. Harari stresses that the solidarity of countries must be implemented through a global share of information on how to combat the virus and what anti-virus practices have been developed by each country. The pandemic has also intensified the problems of help from rich countries to the poorer ones: assistance with equipment, medical personnel, economic cooperation (Harari, 2020).

Throughout its history, humanity has experienced many epidemics and pandemics, and "having come to the end of its ordeal", it went on. But there is a question about the important foundations of humanity in the future?

Summarizing the role and importance of solidarity, the following imperative should be stated as the driving factor of the world now: "Socially and Spiritually - close, physically - at a distance."

One has to admit that, although human consciousness is quite an inert phenomenon, however, in conditions close to catastrophic, one rejects all prejudices and tries to think rationally. Today we pay dear for our impudence not only in the days of Modernity, as has been repeatedly said by postmodern philosophers, but also in the days of Postmodernity. G. Markus emphasizes that "coronavirus reveals the systemic downsides of the dominant ideology of the 21 st century. First of all, the erroneous belief that we can achieve civilizational and moral advance only through scientific and technological progress" (Markus, 2020). Although the philosophy of postmodernism emerges as a 
reaction to the rationale and logocentrism, it clearly failed to complete its mission ... "There is no real progress without moral progress" (Markus, 2020). Today, once again we have been given the opportunity to reassess all actions against nature, against man, and against society.

Transformation of Values during a Pandemic.

One has to admit that when the global situation changes, human values should change as well. The attitude "beneficial to myself" should be replaced with the "beneficial to others". Such a mindset depends on the person's understanding of himself, his perception of himself as an individual, a citizen of his country, a citizen of the planet. Using P. Sorokin's reflections on universal altruism, global solidarity and the methods of its formation, namely the formation of human values, we will analyze the change in values during a pandemic.

1. Old values are already being reassessed now. Regardless of the fact that the world lived in the "post" era, material values retained their significance, many of contemporaries lived, or drew close to the luxury format. Now, sitting in the closed space of their own homes, no one can show the attributes of wealth. This will reduce the demonstrative use of expensive goods, and on the contrary, environmental friendliness, convenience, economy will be appreciated. We are on the verge of conscious consumption on the basis of the price-quality balance.

Interestingly, according to the British economic theorist and consultant Umair Haque: "it was the inequality that caused the COVID-19 epidemic; the causes of this pandemic are poverty, a lack of health and environmental protection at a global level. Therefore, even small actions such as a bat having bitten someone or been eaten by someone in Wuhan can have disastrous global consequences. That is why all of us, if we are intelligent and serious-minded people, should consider building of a fairer world." And further, "An important planetary lesson of COVID-19 is that the virus strikes people regardless of their social and economic background. Poverty, forcing citizens to eat unacceptable things by buying them in dirty markets in unsanitary conditions and restricting their access to normal health care, is a threat to humanity as a whole. If I can catch your illness, then an unfair world is the most dangerous thing of all (quoted by: Doroshenko, 2020). The virus has no material, racial, denominational boundaries, it strikes both the poor and the rich, both yellow and white, both Buddhists and Christians. All people are equal before the virus.

2. Postmaterial values becoming relevant.

Western civilization has been making a long way to postmaterial values for a long time. It was necessary to accumulate enormous material wealth, to be sated with it, in order to desire something more. The transition to postmaterial values is a problem of existential choice, and probably, most people are not ready for that choice. Postmaterial values need a developed social imagination, and wisdom to be opposed to a lifestyle that has been shaped for centuries.

Recently, such value as the need for subjective occupational satisfaction, satisfaction from one's own participation in public and private life has been found along with quality of life indicators. The subjective life satisfaction opens an axiocentric era of humanity, determined not by the commodity and contemplative mass of the produced things, but by the depth and completeness of human meaning. Unlike anti-material and partly intangible values, postmaterial values are aimed at communication and dialogue; they are of a panhuman nature. Perhaps, it is in the conditions of post-modernity, when a person realizes what it means to live among others and the Other. The problem of choice and responsibility for oneself and for the Other adds a special connotation to it (Dodonova, 2011).

Put simply, it is the value of freedom, friendship, family, love, and self-actualization. At the same time, during and after the pandemic, the existential problems of the people, which will lead to a re-evaluation of their own lives, of the meanings that were principal during life will intensify. As a result of the pandemic, there is a divorce outbreak in China today. The individualized life of each family member failed the challenge of being together for 24 hours a day. The craving for recognition, which actively drives an individual in a big society, does not work very well in one's own family, where tolerance, patience, love, and respect for one's loved ones must be the main rule.

While the pandemic is assessed in a negative way in general, the founder of a forecaster Trend Union Lidewij Edelkoort is optimistic about COVID-19, seeing it as a "quarantine of consumption". "We must be very grateful for the virus because it may be a reason we will survive as a species" (quoted by: Doroshenko, 2020). Five years ago, she emphasized that the world fashion industry had become its own parody, now Edelkoort predicts the decline of consumption, a radical revision of human habits and values, slowing of consumer goods manufacturing, a new wave of labor reforms, the era of which were opened by the bubonic plague in medieval Europe.

Changes in values always bring about changes in different areas of human activity. In rich countries, consumption patterns lead to such a depletion of global resources, which threatens the future of the world. Preservation of wildlife requires an immediate reduction in consumption in the "most developed countries" in several areas substantially, since many natural resources are nonrenewable. The philosophy of the consumer society does not take into account the fact that there are no resources on the earth so that all people could live like that, it shapes a view of life in which money and material desires of a person are the key to a happy life. The centuries-old philosophical wisdom, appealing to humanity to maintain moderation, has been forgotten.

3. Environmental values and the problem of responsibility for nature.

During the pandemic, the problem of human responsibility for its actions, not only to oneself, or to their relatives, but also to society and nature, has become a critical question. Previously, when scientists talked about the relevance of environmental thinking, their opinions were usually taken carelessly, or if it was taken into account, no real or very few environmental protection measures have been done.

Today environmental consciousness has become relevant, which is understood as a set of values-based orientations, notions and knowledge of people both about the nature itself and about the relationship between society and nature.

According to R. Mitchell, R. Dunlap, R. Inglehart, the main characteristics of environmental consciousness include: environmental concern, mobilization of moral resources, ability to identify the source of the threat and a social entity responsible for it, the recognition of a healthy and safe living environment as a social value; individual mobilization - awareness of the need for personal participation in protest, creative or other forms of collective action; cognitive mobilization - formation of willingness to 
act on the basis of the comprehension of the information on environmental risks and hazards.

Today, there is a lot of evidence that after the shutdown of industrial enterprises, the air becomes cleaner, namely smog over China dispelled, dolphins and swans returned to the canals of Venice, and it became suitable for the animals. Man did much damage to the planet. We must realize that development and nature are not separate concepts and that problems in either of these areas cannot be successfully resolved separately from the other. Nature gives us resources for development; its condition is an important criterion, and preservation is a subject of constant attention in the development process. Successful development needs a policy that takes environmental priorities into account. Preservation of the Earth's natural resources and rationalization of their use are among the most pressing issues that are currently faced by people, societies, and states. Man plunders his own wealth. Of course, this does not mean that we have to live in the Stone Age again, but the humane use of planet resources and the humane attitude to nature should become a priority when building new businesses. The entrepreneurial paradigm needs to be changed, namely: the ability to negotiate, to trust each other in business, to cooperate, to seek winwin solutions, to take into account the interests of a fellow man.

But when it comes to the link between pandemics and climate change, many scientists are pessimistic about the issue. For example, François Gemenne, a member of the Intergovernmental Panel on Climate Change, and Anneliese Depoux, a health expert, emphasize that: "Climate change demands our solidarity that goes beyond state borders, and not just stays within their territories. One may question the efficiency of border closure as a measure to slow the spread of the virus. However, there is no doubt that greenhouse gases have no boundaries. In addition, measures to combat coronaviruses are caused by an emergency: we have not chosen them, we are only forced to accept them. Whereas in contrast, the measures to combat climate change should be selected by us" (Gemenne, Depoux, 2020).

The restrictions imposed on us due to the coronavirus can be the impetus for more conscious behavior when protecting the environment, says Kiss Soma Ábrahám: "One can only feel joy that the environmental and air pollution that has come out from excessive capitalist production has dropped because of the epidemic. Such experiences can be as an impetus to creating a world that grounds on a more equitable distribution of property and aims to ensure the planet's population existence based on sustainable development principles" (Kiss, 2020). From this perspective we can see that the ecological reflections of scientists produce not environmental messages, but the economic and social ones.

4. The values of natural law become relevant: the right to life, the right to health, the right to freedom, as well as the right to demand from the state the protection of one's natural rights.

It should be acknowledged that in the $21^{\text {st }}$ century, human life and health constitute undeniable value. And the actions of states during the pandemic have demonstrated this. You must admit that 25 years ago, humanity would not pay much attention to the coronavirus. Certainly, there would have been some precaution, but the state would have refrained from such a grandiose shutdown of public life. There were many reasons for this, in particular, the results of postmodern philosophy: postmodernism, communicative philosophy, philosophical anthropology, phenomenology, in which a human is the highest value in the world.

According to Michel Foucault, health is the centerpiece of modern management, which he called "biopower." The state manages, monitors and punishes people through medicine and mental health. "There is an unstated agreement between modern states and citizens based on the state's ability to guarantee the safety and physical health of citizens" (quoted by: Latour, Illusion, Jean-Luc, 2020).

$M$. Foucault focuses on two ways in which the authorities function, namely, "citizens-city" and "shepherd-flock" (Foucault, 2013). The first was introduced in antiquity and the second is specific to Christian pastorate, which focuses on the issues of life and death, health and poverty, humbleness and salvation of all mankind. Embodied in a biopolitical control over the life of citizens, such formation laid the foundations of the modern state. Today, the concern and control of the state is not so much about the lives and well-being of individuals as their activities to support their lives.

According to V. Fadeev, "the modern state is less and less capable of showing pastoral care, even in situations when no one else can do it. Moreover, concern for the population is increasingly adopts a shape of prohibitive measures and restrictions on civil liberties" (Fadeev, 2020).

The question arises about which type of political system is most capable of providing a rational solution to the problem: authoritarian, populist or democratic? As we see, South Korea, Taiwan, and Singapore have shown an adequate resistance to the pandemic - these are democracies, not countries governed by authoritarian leaders or populists. It is clear that communication between the state and citizens should be based on a trust that has not been established for one day, but has been gained for years; this is a trust in the authorities, the health authorities, and the mass media.

Although tracking tools have been and are being used in South Korea, Singapore, and Taiwan that coped with the virus fairly quickly; these included both electronic wristbands and geolocation, and tracking by means of TraceTogether via Bluetooth. This means the government did not act so softly and democratically to overcome the virus, as reported in the press. In general, there are two categories of population tracking programs: tracking technology (geolocation tracking) and contact tracing (tracking contacts between users).

Today, not only "over-the-skin surveillance but also under-the-skin surveillance" is being implemented in China - now the authorities want to know the temperature of your finger and the subcutaneous pressure. Then the authorities will want to know your emotions and your preferences. The people in control, who were easier to govern, were the subject considered by the legists, but they could not provide more modern means besides reports to the authorities.

Moreover, not only in China, but also in Western Europe, there are patrols of streets, closed areas, blocks, measuring of the temperature of passersby using infrared cameras without the knowledge or permission of the person. Such actions are criticized by scientists. When choosing between health and personal life, people are forced to choose health, but "we can choose to protect our health and stop the coronavirus epidemic not by instituting totalitarian surveillance regimes, but rather by empowering citizens" (Harari, 2020).

Andrii Repa notes that "here it is, a new reality, not a 
movie: geolocation, surveillance cameras, disinfection robots, police robots, facial recognition, videos of impressive detentions of offenders, special movement permits, electronic databases of infected persons, individual codes, wristbands, infrared scanners for temperature measurement, facial recognition for the purchase of goods, digital archiving of each individual. And especially - the so-called "electronic prisons" i.e., tracking a person through a mobile application in a smartphone" (Repa, 2020).

One could say that this is an urgent tool for biometric surveillance and management during a pandemic, but there is a high risk that these forms of human manipulation will become part of post-pandemic practices on an ongoing basis. Behind the great concern for citizens there lies so-called "secucracy", which manifests itself in strengthening the police form of public administration. Many modern intellectuals, namely A. Damasio, Y. Harari, G. Markus, J. Butler, have warned that after a pandemic, humanity will part with freedom, at least it will be distorted and destroyed in many ways. The health of the individual will be important for the health of the whole society, which will manifest itself in the social pressure on the individual with the requirements to maintain hygiene, to take control of their health, and the forms of persecution, harassment and hatred are not excluded.

The physical condition will become a "pass card" to social and political life, which will negatively affect the tolerance - the Other will be perceived as a stranger.

As far as populist regimes are concerned and their fight against pandemics, one can manipulate people's minds for a long time, but when there is a threat to life, one must respond quickly, adequately and honestly. And the populists do not have the trust resources to it. Populism is interesting when it is inexpensive, and it is not people's lives that pay for it.

\section{Conclusions}

1. Today, a barrage of information may be found on social media, which is difficult to manage even for an experienced user and rational human. Some write about the apocalypse, the second ones say that we are once again misled, while the others are trying to increase their wealth; the third ones write about the insidiousness of China, and the forth ones write about the need to rearrange social relations to preserve humanity. One may choose an "information cocoon" to one's taste in which one will be emotionally comfortable. Behind all this infoglut, which is buzzing and roaring, we should consider the really important changes that have happened and will happen to us now and then. Probably, the problem of changing public relations is the most rational, though challenging to achievable. It should be assumed that that within the new value system, for example, overcoming poverty is not a decrease in the number of the poor, but an increase in the number of persons with middle incomes. In practice, it is a model of new social justice and new social solidarity, which do not contradict the spirit of capitalism, but are in harmony with it. The whole world mentally must gradually move from the so-called "upmarket", "glamorous" and "luxurious" to more rational and considered models.

There will be no return to the normal reality that existed until the pandemic outbreak. The humanity will definitely develop other forms of communication that will make it possible to exist in new conditions. But, along with the coronavirus, humanity can get sick of "political viruses of the twentieth century", namely totalitarianism and fascism. And it's even more dangerous than a coronavirus.
2. Although it have been considered utopian for a long time, today the concept of P. Sorokin's creative, universal altruism may become a new / old form of social solidarity, which is necessary amidst the pandemic and postpandemic life of humanity. The basis for its implementation comprises the universal values and understanding by the global community that we are all connected by the "lace of humane attitude". We should also pay tribute to the national leaders, namely A. Merkel, who, on April 23, gave a speech at the Bundestag, and outlined some of the global altruism provisions, emphasizing that the world is unified and that the security of one country depends on the security of another country. Therefore, the actions of the states at the beginning of the pandemic and the actions of the states today are different. Changes in the situation in the world and in the country prompt to change an opinion.

3. During and after a pandemic, significant transformations will affect a balance between material and postmaterial values. It is clear that material values will remain, but the excessive luxury will be receded into the background, and people will increasingly focus on the "pricequality" format. At the same time, the role of post-material values will increase greatly, not so much the values of personal self-actualization, as the values of family, love, friendship, knowledge, mutual assistance, humanity, tolerance, indifference to the other. One may predict the increase in the value of the vital or existential values associated with the preservation of life on Earth, human existence, environmentalism, global solidarity, and accompanying values of natural law: the right to life, the right to health, to self-preservation. Probably, during the critical periods of the world history they are perceived by a human as the most essential. However, people must be able to distinguish between genuine concern for the lives of citizens and the accretion of disciplinary authority that will control both the spiritual and physical life of a person. Let's keep our eyes open.

\section{REFERENCES}

Aleksandrova, O. \& Dodonov, R. \& Vinnikova, N. (2019). Postmaidan Ukraine: Middle Class in the Shadow of Reforms. Studia Warmińskie; The Studies of Warmia. № 56, 439-455. DOI: https://doi.org/10.31648/sw.4315

Dodonova, V. (2011). Postneklasychnyy dyskurs sotsialnoyi ratsionalnosti. Donetsk: DonNU. 345 p. (In Ukrainian)

Dolgov, A. (2014). Istoriko-metodologicheskaya rekonstruktsiya teorii sozidatel'nogo altruizma Pitirima Sorokina. Sociologicheskiie isledovaniia. 9: 104-114 (In Russian).

Doroshenko, K. (2020). Svitovi intelektualy pro naslidky pandemiyi koronavirusu dlya lyudstva. Retrieved from https://suspilne.media/20654-svitovi-intelektuali-pro-naslidki-pandemiikoronavirusu-dla-ludstva/ (In Ukrainian)

Fadeev, V. (2020). Peripetii pastyrstva. Koine. Retrieved from https://clck.ru/PHw4a (In Russian).

Foucault, Michel (2013). Politics, Philosophy, Culture. Interviews and Other Writings, 1977-1984. Routledge, $356 \mathrm{p}$.

Gemenne, François \& Depoux, Anneliese (2020). "De la crise du coronavirus, on peut tirer des leçons pour lutter contre le changement climatique". Le Monde. Retrieved from https:// clck.ru/PHw5V

Harari, Yu. N. (2020). The world after coronavirus. The Financial Times, 20.03.2020. Retrieved from https://clck.ru/MxP7a

Kiss, Soma Ábrahám (2020). A dolgozók fogják igazán megsí nyleni a koronaví rus-járványt anyagilag és egészségügyileg is. Mérce. Retrieved from https://clck.ru/PHw7d

Klimkin, P. (2020). Postpandemichnyy mir: Ukraina dolzhna vybit sebe mesto $v$ novoy realnosti. Liga.net. Retrieved from https:/ 
/www.liga.net/politics/opinion/postpandemichniy-mir-ukrainadoljna-vybit-sebe-mesto-v-novoy-realnosti (In Russian)

Latour, Bruno \& Illusion, Eva \& Jean-Luc, Nancy (2020). Yakyy svit pislya pandemiyi? [What is the world like after a pandemic?] Translated by A. Repa. Politcritica. Retrieved from https:// politkrytyka.org/2020/03/31/yakyj-svit-pislya-pandemiyibruno-latur-yeva-illuz-zhan-lyuk-nansi/ (In Ukrainian)

Marcus, Gabriel (2020). Sistemnyye uyazvimosti [System vulnerabilities]. Politcom. Retrieved from https://politcom.org.ua/sistemnye-ujazvimosti (In Russian)
Repa, A. (2020). Chudesnyy novyy svit dlya novoho stolittya. Politcritica. Retrieved from https://clck.ru/PHwFP (In Ukrainian)

Shapiro, J. (2020). Transatlanticheskie otnosheniya i koronavirus. Russia in global politikie. Retrieved from https://globalaffairs.ru/articles/transatlantica-i-koronavirus (In Russian)

Sorokin, P. (1947). Society, culture, and personality: Their structure and dynamics. A system of general sociology. N.Y.: Harper \& bros, 39-42, 63-66, 359-364, 367-379.

Sorokin, P. (2002). The Ways and Power of Love: Types, Factors, and Techniques of Moral Transformation. Philadelphia: Templeton Foundation Press.

Віра Додонова,

Київський університет імені Бориса Грінченка (м. Київ, Украӥна)

e-mail: v.dodonova@kubg.edu.ua, ORCID 0000-0002-4282-5495

Роман Додонов,

Київський університет імені Бориса Грінченка (м. Київ, Украӥна)

e-mail: rdodonov@kubg.edu.ua, ORCID 0000-0003-1598-499X

\section{ТРАНСФОРМАЦІЯ СОЦІАЛЬНИХ ЦІННОСТЕЙ ПІД ЧАС ПАНДЕМІЇТА ПРОБЛЕМИ ГЛОБАЛЬНОЇСОЛІДАРНОСТІ}

У статті проаналізовано соціально-етичну ситуацію у світі під час пандемії COVID-19, зокрема, загальну тенденцію до закриття кордонів, ізоляції, національного егоїзму, збільшення тотального контролю та безпекократії. Задіяна в статті методологія дискурс-аналізу дозволила узагальнити різноманітні оцінки феномену глобальної пандемії, включаючи ставлення до солідарності, випробовування загальнолюдських цінностей, наповнення концептів, що аналізуються, конкретним політичним, етичним, соціокультурним змістом. Феноменологічний метод надав змогу проаналізувати повсякденний досвід людей, постраждалих від пандемії. Компаративний підхід дозволив порівняти прояви боротьби з епідемією в різноманітних політичних системах. У статті згадується концепція глобального альтруїзму П. Сорокіна, яка в сучасних умовах набуває нової інструментальної функції, спрямованої на колективне виживання. Констатується, що в ході пандемії людством переосмислюється співвідношення матеріальних і постматеріальних цінностей на користь останніх. Ізольованість у замкненому просторі житла не сприяє демонстративному споживанню дорогих товарів і предметів розкоші навіть у середовищі багатіїв. Навпаки, після епідемії будуть цінуватися зручність, економічність, екологічність, тобто стандарти середнього класу на основі балансу "ціна-якість". Прогнозується загострення вітальних проблем, які приведуть до переоцінки власного життя, смислів, які раніше були визначальними в житті людей. Значно актуалізуються цінності свободи, дружби, сім'ї, кохання, самореалізації, знання - принаймні для тієї частини суспільства, яка піднялась над рівнем екзистенц-мінімума. Пандемія продемонструвала, що жага визнання в якості основного мотиву поведінки людини в великому соціумі, не зовсім вдало спрацьовує у власній сім'ї, де головним правилом має бути толерантність, терпимість, любов та повага до ближнього. На перше місце вийдуть цінності природного права: право на життя, право на здоров'я, право на свободу, право вимагати від держави забезпечення своїх природних прав, а також екологічні цінності та проблема відповідальності. Певно, що в критичні періоди розвитку світової історії вони усвідомлюються людством як найважливіші.

Ключові слова: COVID-19; альтруїзм; безпекократія; влада; екологія; здоров'я.

(c) Vira Dodonova, Roman Dodonov

Надійшла до редакції: 05.05.2020

Прийнята до друку: 20.05.2020 